\title{
ARTISTS AGAINST GENTRIFICATION: COORDINATORS OF DIFFERENT PEOPLE IN AN INNER-CITY AREA OF OSAKA, JAPAN
}

\author{
Shiro Horiuchi* \\ Faculty of International Tourism, Hannan University, 1-108-1 Amamiminami \\ Matsubara, Osaka, Japan 580-0033 \\ E-mail: horiuchi.shiro@gmail.com
}

Published online: 25 January 2022

To cite this article: Horiuchi, S. 2022. Artists against gentrification: Coordinators of different people in an inner-city area of Osaka, Japan. International Journal of Asia Pacific Studies 18 (1): 79-105. https://doi.org/10.21315/ijaps2022.18.1.4

To link to this article: https://doi.org/10.21315/ijaps2022.18.1.4

\begin{abstract}
Gentrification, often characterised by an influx of new residents who displace established locals, has impacted cities across the world and is accelerated by the growth of global capital and the development of neoliberal governments. Artists can counter the process by using their art to promote justice and community development. This paper explores the influence of artists on the community of Baika-Shikanjima, an inner-city area of Osaka, where many creative individuals have aggregated for more than a decade. At present, the area seems to be untouched by gentrification. The findings of this field study indicate that most artists earn an income through other part-time jobs or by managing small businesses. Despite their meagre earnings, these artists live comfortably thanks to affordable housing, products, and services in the area. The artists exhibit or perform their work for other artists, tourists, and residents. The audience members or participants interact with each other during these performances. The study suggests that artists in this area counter the course of gentrification simply by pursuing their activities and rooting them in the community and daily life of the area. Furthermore, their activities seem to create public spaces through which marginalised groups and individuals are provided the opportunity to engage with other residents. The artists could be regarded as outsiders or authentic tourists who integrate into the local community. Although globalisation accelerates gentrification in many areas of Osaka city, this case study shows that a more sustainable inner-city development is possible if artists are involved in community life.
\end{abstract}

(C) Penerbit Universiti Sains Malaysia, 2022. This work is licensed under the terms of the Creative Commons Attribution (CC BY)(https://creativecommons.org/licenses/by/4.0/). 
Keywords: Artists, creative class, gentrification, Osaka, daily-life

\section{INTRODUCTION}

Many cities in Japan have lost their populations and are in the process of shrinking (Pallagst et al. 2013). Although many of these cities had once flourished as manufacturing areas, they have suffered from the post-industrial shift to service industries from the 1960s onwards. The change resulted in an overall loss of employment, consumption, social infrastructure, communities, residents' collective identities, employment opportunities and, consequently, population. To increase or maintain their populations, cities are utilising several strategies, such as using creative individuals to uplift the economies and communities as a powerful strategy to regenerate the cities (Florida 2002). As a result, inner-city areas often fall victim to gentrification.

For more than 50 years, gentrification has been a central theme in urban redevelopment (Lees et al. 2008). Traditionally, gentrification refers to a replacement of inner-city areas' residents. In other words, an influx of new (often wealthier) residents displace longstanding residents (Glass 1964: xviiixviix). Experts in urbanisation have presented several possible explanations for the mechanisms of gentrification, and these can be classified into two major groups (Hamnet 1991: 185-188). The first explanation stresses the consumerrelated demands of the immigrant residents who often belong to the new middle-class (Ley 1996). These new residents are usually young singles or childless couples with a double income, employed mainly in the professional, administrative, technical, and managerial service sectors. Furthermore, they are highly educated and earn substantial incomes. They favour consumption and prefer to live in inner-city areas instead of commuting from suburban areas and living in large homes. Others explain gentrification by emphasising the role of developers (Smith 1996: cp. 3). Real estate value in inner-city areas is high because of their close proximity to city centres. Developers take advantage of the discrepancy between current property values and potential land values by renovating old buildings or constructing condominiums to attract new residents with high incomes.

In both scenarios, members of the creative class, such as artists, often initiate gentrification. They favour renovated old buildings and prefer to spend their time and money at fashionable places such as art galleries, boutiques, and cafes. Later, new residents, including administrative or professional jobs, live 
in new buildings such as condominiums. New residents rarely interact with other locals because their lifestyles are different. An influx of new residents also increases tourism in the area, and developers make further improvements to accommodate new residents and tourists. As a result, property prices increase and while longstanding residents with low incomes are unable to afford living in the area, others are pressured to leave. In this way, many local communities have disappeared from inner-city areas across the world and are seen as victims of gentrification brought about by middle-class needs and real estate developers' opportunism.

Gentrification, often associated with England and North America, occurs across the globe, albeit in different contexts (Atkinson and Bridge 2005; Lees et al. 2015, 2016; Gravari-Barbas and Guinand 2017). The phenomenon is considered a result of the growth of global capital and neoliberal governments (Sassen 2001: cp. 4; Smith 2002: 437-446). The financial and information industries lead the economies in cities; however, unskilled workers in the urban service sector do not have a significant impact on the economy because their incomes are too low. As a result, inequalities among residents in cities are growing. Furthermore, neoliberal urban governments cannot regulate the global market and offer affordable housing. Instead, these movements become agents of the global market with no control over estate value or property prices. Some authoritarian states even gear urban land markets towards generating considerable revenues for private development and finance sectors.

New York and London - two of the leading global cities - have fallen victim to super-gentrification (Lees 2003; Butler and Lees 2006). Because of excessively high real-estate prices, even the middle-classes have been forced to relocate to less developed and poorer suburban areas (Florida 2017: cp. 8). Tourism also accelerates global gentrification, and, unfortunately, it does not affect only tourist destinations but the residential areas of longstanding residents too (Gotham 2005; Urry and Larsen 2011: cp. 8). Furthermore, cities try to gain capital and tourists to accelerate economic development with little regard to their residents' dissatisfaction, protests, and resistance (Colomb and Novy 2016).

Only a few studies have explored artists' awareness of their potential contributions to gentrification, city justice, and community development. In the cases where artists function independently from the logic of capitalism or the government, the intricacies of their interactions with longstanding residents remain unclear. Therefore, this paper aims to address these issues by 
exploring the possible contributions that creative individuals-particularly artists - can make. This is done by exploring a case study in an area of Osaka in Japan, Baika-Shikanjima. The paper argues that, although they are often regarded as catalysts for gentrification, artists can help to regenerate residential inner-city areas by cooperating with longstanding residents.

\section{GENTRIFICATION AND ARTISTS}

Artists often colonise depleted inner-city areas, as was first pointed out by Zukin (1989), who focused on the role of artists in New York's depleted SoHo area in the 1980s. Abandoned lofts are excellent locations for art studios and artist residencies, and the rent and commodities in these areas are mostly affordable. Artists also benefit from being in the inner-city area, because wealthy consumers and corporations can easily access their work. By managing their small and independent businesses in these areas (such as art galleries, boutiques, and cafes), artists and residential entrepreneurs contribute to the accumulation of cultural capital and attract tourists, thereby improving the area.

Attracting tourists is a common strategy used by cities to increase creativity and ultimately flourish (Ley 2003; Cameron and Coaffee 2005). Many artists also aggregate in cities to get financial support from governments, collaborate with companies like design firms, or attract customers (Markusen 2006; Markusen and Schrock 2006; Woronkowicz and Noonan 2019). Artists can also create public art or performances in depleted areas, and, in this way, create places with aesthetic character (Grodach 2010). Furthermore, as Stern and Seifert (2010) point out, housing markets improve and real estate value increases in the areas where artists aggregate. Longstanding residents are eventually forced to leave the area because they can no longer afford to live there. Hence artists often work as catalysts of gentrification.

Gentrification, therefore, poses a dilemma for artists. Artists gain by improving the inner-city area and welcoming new artists, capital, and tourists. Unfortunately, as developers continue to improve these areas and the real estate value increases, artists cannot afford to reside there for long and they too are ultimately displaced. While some artists may be able to stay on by servicing the new middle-class residents, they become dissatisfied with the conditions or when they are unable to engage themselves in a "bohemian lifestyle" (Lloyd 2010) through art. 
However, artists do not necessarily contribute to gentrification; they often oppose the process through the idea of a "right to the city" (Lefevre 1968; Harvey 2012) or the "Third Space" (Soja 1996). Within the contexts of relational (Bourriaud 2002) or participatory art (Bishop 2012), artists are considered coordinators of several subjects; in other words, they collaborate with ordinary people, particularly marginalised groups such as persons with disabilities, the poor, foreigners, the LGBTQ community, and children. In Toronto (Canada), for example, art festivals have been shown to promote interaction between neighbours that could establish a basis for future communication and to strengthen social bonds, although the festivals are irregular and temporary (Enright and McIntyre 2019). In Baltimore (U.S.), for example, a group of artists decided to collaborate with marginalised groups to help them keep their occupied space. Although the artists were eventually displaced by the city government, the space had the potential to evolve into a base for inclusive arts and community development projects (Rich 2019). A collaboration between artists and residents could, therefore, initiate a participatory democracy in the area by encouraging diverse groups of people to interact. Fainstein (2010) regards democracy, diversity, and equity as the essential components of city justice, and these are often enabled through art. Artists also contribute to community development by starting, for example, a local business that can function as a bottom-up resistance against top-down urban development (Jacobs 1961). Community businesses further support development in favour of established residents, including marginalised groups, by building and expanding business-to-business (B2B) and business-to-consumer (B2C) networks in and across dilapidated areas (Horiuchi 2017a).

In Japan, numerous art projects have been completed since the end of the 20th century with the goal to revitalise regions and grow creative industries. Some well-known art projects, such as "the Setouchi Triennale" and "the Echigo-Tsumari Art Triennale", are held in rural depopulating areas of Japan, succeeded in facilitating regional revitalisation and community development (Tanaka 2019; Cai et al. 2020). Unfortunately, most art projects in Japan lack financial support from large corporations or the government; in fact, artists are often exploited in the name of regional revitalisation (Fujita 2016: cp. 1). As a result, artists struggle to develop their careers independently from the logic of capitalism or governmental policies. 
With regard to the successes of these revitalisation projects, artists face other challenges too. In the old capital of Nara, for example, an art project aimed at restoring abandoned traditional buildings by welcoming artists-inresidence succeeded in repurposing these as communal spaces. However, the artists struggled to communicate with the residents in order to encourage them to rethink their community and culture (Horiuchi 2017b). Artists were also invited to use their art to improve the area of Yokohama, in line with the municipality's policy of constructing a city characterised by creativity. Despite their valuable contributions, however, the artists were still regarded as precarious. Yet, they chose to focus on their identities as creative individuals (Kim 2019). Similarly, an artist who decided to involve residents in a depleted area in Osaka faced the risk of low funding, although her outputs had the potential to generate positive change in the community (Novak 2019).

However, few studies have shown how artists are conscious of the possibility of their art for gentrification, or city justice and community development. Particularly when artists are almost independent from the logic of capitalism or the government, their relationship with longstanding residents are unclear. To elucidate the role of artists in different gentrification or regeneration processes, this paper introduces the case study of artists in a depleted area of Osaka city in Japan.

\section{URBAN REDEVELOPMENT IN OSAKA}

During the 1920s, Osaka was the largest city in Japan. The city, then called Oriental Manchester (Osaka City History Compilation Office 1999: 259), was the centre of heavy manufacturing industries and suffered from air pollution. Figure 1, which indicates the population changes of the city over time, shows how the number of residents increased after the end of World War II (WW2). From 1965 onward, however, the city's population started to decline. Those who earned high incomes relocated to the suburbs in search of larger houses and cleaner environments. Those who earned less, had to remain in the innercity areas. However, since 2000, Osaka's population has increased due to urban redevelopment. 


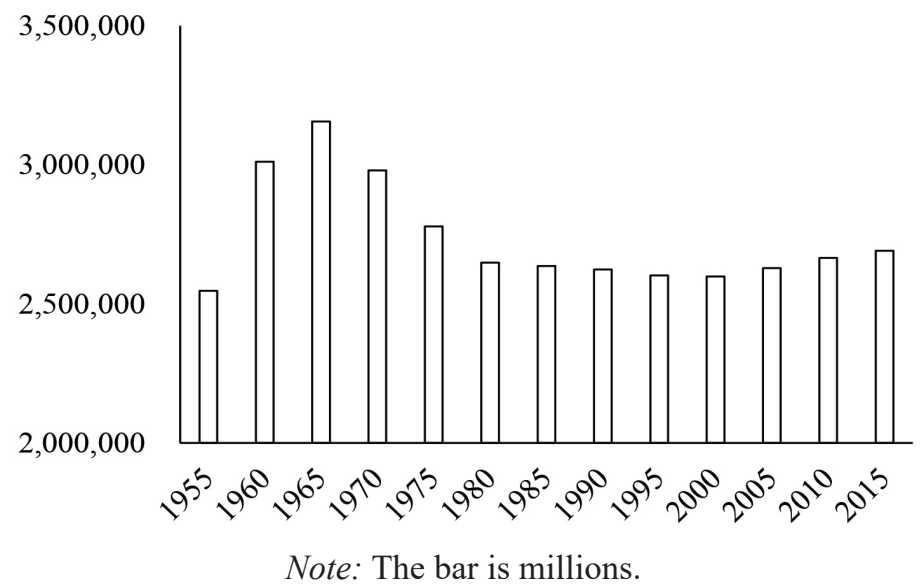

Figure 1: Population of Osaka city [as retrieved from the Public Information Division, Office of the Mayor, City of Osaka (https://www.city.osaka.lg.jp/toshikeikaku/ page/0000379310.html)].

Since its transition from manufacturing industries to service sectors, Osaka has been working towards establishing new industries. The Osaka government has deregulated the construction of large condominiums to support back-to-the-city movements (Ajisaka et al. 2019). In addition, the city's authorities have been working towards establishing Osaka as a global city by increasing the influx of global capital and international tourists. In this regard, Figure 2 shows the total overnight stays by domestic and international tourists in the city. The total stays by domestic tourists are almost stable, whereas the number of stays by international tourists has doubled or tripled over the last few years. A planned expo in 2025 may further increase the number of international tourists, in anticipation of the end of the COVID-19 pandemic. The government also plans to utilise the expo venue by developing it into integrated resort facilities (IR) afterward.

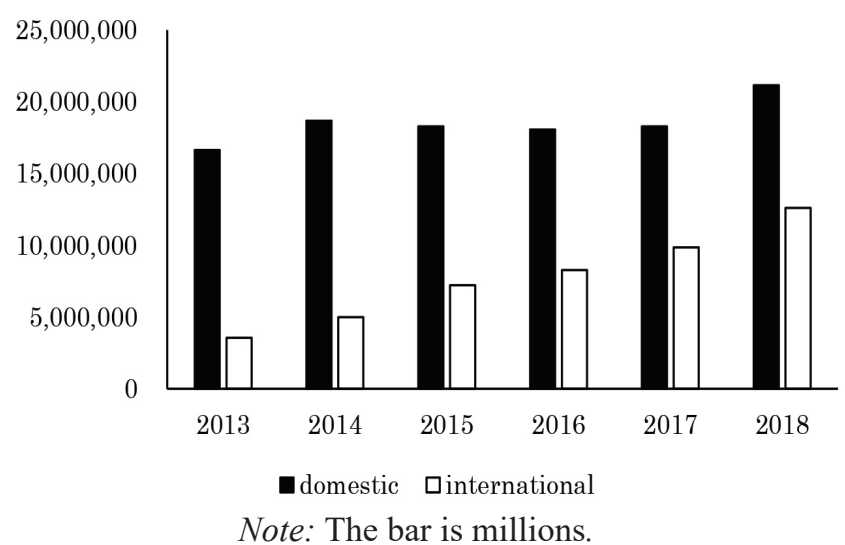

Figure 2: Total overnight stays by domestic (black) and international (blank) tourists at Osaka [as retrieved from the Osaka Prefectural Government (https://www.pref. osaka.lg.jp/kanko/toukei/index.html)]. 
Population recovery initiatives have been concentrated in the central area of Osaka. Figure 3 shows the population changes (2010-2015) and the elderly and child ratios (2015) in the 24 wards in the city. The population has increased in the central four wards (Nishi, Naniwa, Kita, and Chuo-labelled $4,8,23$, and 24, respectively). In these areas, the elderly and child ratios are under $20 \%$ and $10 \%$, respectively. These values suggest that the areas are favoured by younger residents without children, which is an indicator of possible gentrification. Large condominiums are being constructed mainly in the central four wards.

(a)

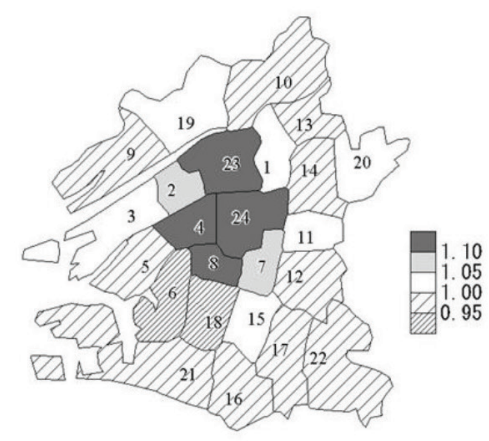

(b)

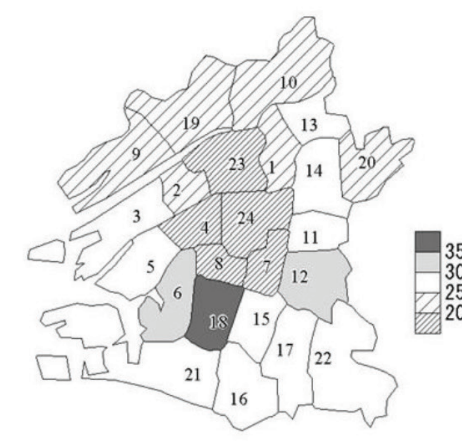

(c)

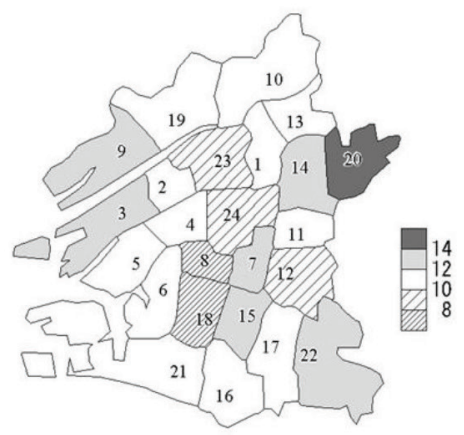

Notes: Labelled in the figure; 1: Toshima, 2: Fukushima, 3: Konohana, 4: Nishi, 5: Minato, 6: Taisho, 7: Tennoji, 8: Naniwa, 9: Nishiyodogawa, 10: Higashiyodogawa, 11: Higashinari, 12: Ikuno, 13: Asahi, 14: Joto, 15: Abeno, 16: Sumiyoshi, 17: Higashisumiyoshi, 18: Nishinari, 19: Yodogawa, 20: Tsurumi, 21: Suminoe, 22: Hirano, 23: Kita, and 24: Chuo.

Figure 3: (a) Population change 2015/2010, (b) Elderly ratio (> 64 years) at 2015 (\%) and (c) Children ratio (<15 years) at $2015(\%)$ (as retrieved from https://www.stat. go.jp/data/kokusei/2015/kekka.html).

The redevelopment in these areas significantly affected the original communities. Kirmizi (2016, 2019), for example, reported gentrification in the Horie area of the Nishi ward, where longstanding residents continued to manage furniture shops and preserve their identities. New residents moved into the area's large condominiums, and unfamiliar and novel shops and cafes opened in the area and made it trendy. These changes attracted tourists to the area, and although established locals accepted the inevitability of change, they were concerned about the loss of identity and place. According to Kawaguchi (2008), tourists created their own images of Horie and associated it with cool fashion, for example. Ajisaka et al. (2019: cp. 8), on the other hand, explored the perceptions and experiences of new residents in the area. According to their survey, which was distributed among residents of condominiums that were recently constructed in the Kita and Chuo wards, the new residents rarely interacted with their neighbours, which indicates a 
loss of a sense of community. Similarly, Fujitsuka (2017: cp. 10) conducted research on the effects of condominium construction in the Fukushima ward, which is adjacent to the central four wards. His findings indicated that the traditional landscapes (characterised by detached or tenement buildings) and local communities were deteriorating as a result of these constructions. These studies suggest that gentrification most likely occurs in areas where constructions and developments attract new residents and tourists.

With regard to Osaka, not all its areas have undergone gentrification. In some wards, the population changes and the elderly and child ratios show variations. Some wards, for example, show significant depopulation with a high elderly ratio and low child ratio, suggesting the presence of older single residents in small households. These wards include Taisho (Label 6; population change: 0.94 ; elderly ratio: $30 \%$; and child ratio: $11 \%$ ), Ikuno (Label 12; population change: 0.97 ; elderly ration: $31 \%$; and child ratio: 9\%), and Nishinari (Label 18; population change: 0.92; elderly ratio: 39\%; and child ratio: $7 \%$ ). In contrast, a number of other wards show a population increase with a low elderly ratio and high child ratio, suggesting the presence of young residents of large households with children. These wards include Tennoji (Label 7; population change: 1.09; elderly ratio: 20\%; and child ratio: 13\%), Abeno (Label 15; population change: 1.01; elderly ratio: 26\%; and child ratio: 13\%), and Tsurumi (Label 20; population change: 1.00; elderly ratio: $22 \%$; and child ratio $16 \%$ ).

It is not yet clear whether all areas will undergo gentrification now or in the future. Konohana ward (Label 3 in Figure 2), for example, was a combination of islands, moors, and sea, and was consequently isolated from the plain areas of Osaka until the 19th century. Since the 1920s, the area was reclaimed for the construction of factories for heavy manufacturing industries, and large corporations - such as Sumitomo, Hitachi, and Osaka Gas - operated in the area. Housing areas were also developed for the factory workers. However, as a result of the shift from manufacturing to service industries, many factories ceased their operations during the 1960s. While Konohana had once been one of the most dilapidated areas in the city, the government now considers the area as a frontier of redevelopment. In 2001, for example, the most famous amusement facility in Osaka-Universal Studio Japan (USJ) - opened its doors in this ward. USJ is frequented by both domestic and international tourists. Furthermore, the Osaka Expo will be held in this ward in 2025, and plans are in place to build IR in the area. Figure 3 shows that in 2015 the ratio of population change (2015/2010) was 1.02 with 
the elderly ratio and child ratio at $26 \%$ and $12 \%$, respectively. At present, the ward is populated by younger residents with children. The changes in the area, however, make it vulnerable to gentrification.

Baika-Shikanjima in the eastern part of Konohana has been a hub for artists since 2009 when the city's authorities hosted the art project Suito Osaka (or "Water City Osaka"). Map of the area developed by the author using MANDARA, an open free software available from https://ktgis.net/mandara, is as shown in Figure 4. Most of the artists live or run their business in the gray areas. Many artists were invited to participate, and some decided to stay on when the project came to an end. In 2011, a residential property company initiated an art project called Mikke Konohana (Let's Find Konohana), which offered artists the opportunity to display and perform their work. This project gave rise to a number of independent art exhibitions and performances in the area. Figure 5 shows art spots where independent art exhibitions and performances are held. A few of these destinations were featured in the mass media and received attention on Facebook and Twitter or were advertised by word-of-mouth. As a result, many fans of contemporary art visited the exhibitions and participated in performances.

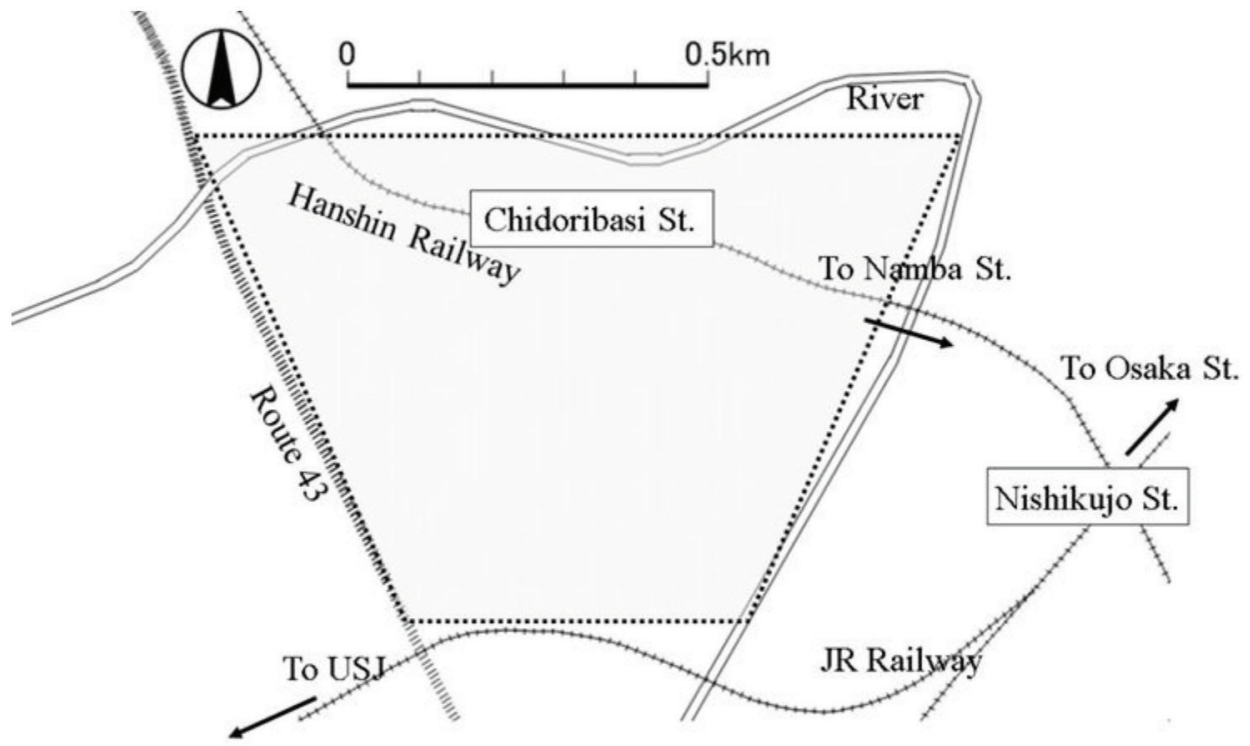

Figure 4: The map of Baika-Shikanjima. 

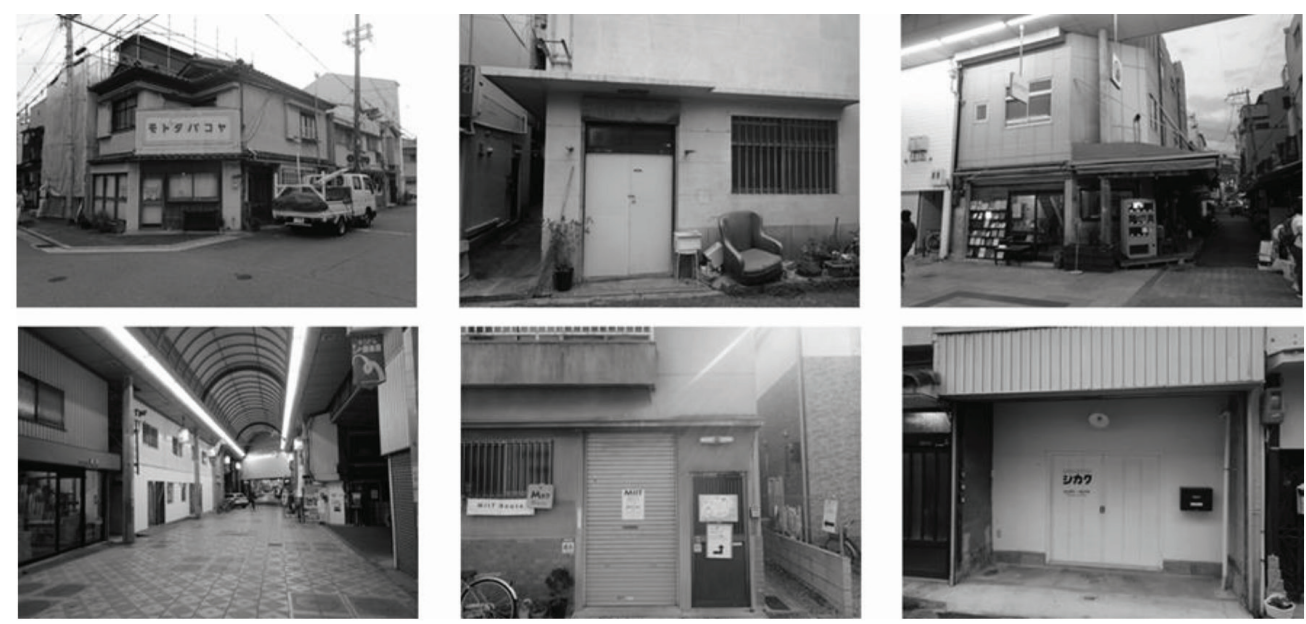

Figure 5: Some buildings for art exhibitions and performances in Baika-Shikanjima.

Baika-Shikanjima is easily accessible from the central areas of Osaka, which adds to its appeal. The Hanshin railway runs through the area, and via this railway, residents can access Namba, Osaka's largest shopping area, within 10 minutes. Similarly, Osaka's largest business area, Osaka station, is a 10-minute commute via the JR railway. In addition, USJ is accessible from Baika-Shikanjima. Residents in Baika-Shikanjima therefore could easily visit the central areas of business, shopping, and amusement in Osaka.

Despite these changes, there are no signs of gentrification in BaikaShikanjima, such as the construction of large condominiums. Figure 6 shows the ratio of residents according to their housing type and height in BaikaShikanjima, the Konohana ward excluding Baika-Shikanjima, and the central four wards of Osaka (Nishi, Naniwa, Kita, and Chuo). In Baika-Shikanjima, nearly half of the residents live in detached one- or two-storey buildings, whereas only one-tenth of the residents reside in condominiums of more than 11 storeys. In contrast, nearly half of all residents in other Konohana and the central four wards live in condominiums that comprise more than 11 storeys. Many detached buildings in Baika-Shikanjima were constructed during the 1950 s to 1960 s. These buildings, which are inhabited by artists and established residents, look neglected in comparison to the large condominiums in the area. It remains unclear why the area, which is well-suited to gentrification, displays little sign of such development. The author pays attention to the role of artists; he assumes that artists work as an obstacle against, rather than a catalyst for, gentrification in Baika-Shikanjima. 


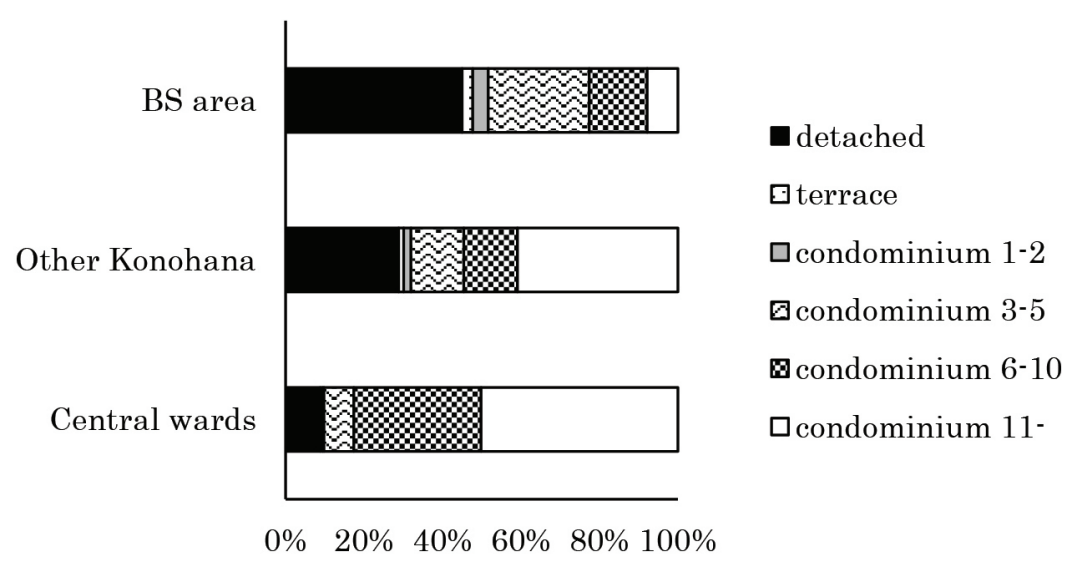

Figure 6: The types and stories of residence in Baika-Shikanjima, Konohana area, excluding Baika-Shikanjima, and the central four wards of Osaka city (as retrieved from https://www.stat.go.jp/data/kokusei/2015/kekka.html).

\section{ARTISTS IN BAIKA-SHIKANJIMA AREA}

As stated earlier, this paper aims to shed light on the lived experiences of new residents in this area, particularly those who engage in a variety of artistic pursuits. Various research methods have been applied to explore these experiences. First, the researcher has been visiting art spots in the area and participating in exhibitions and performances since 2017. In addition, more than 20 residents - including residents who see themselves as artists, shop owners, managers, and entrepreneurs - have participated in interviews since 2018. For the purposes of this paper, however, "artists" refer to those residents who engage in different art forms, including performances, music, design, or curating. These participants were selected by means of a snowball sample, and the sample group resembles Sawangchot's (2016) group of artists in his study of the Konohana area.

With regard to the interviews, the researcher first explained to the participants the focus of the research project, and then collected information about the participants' lives and their views on gentrification. Many of the interviewees were familiar with the concept of gentrification, referring to other inner-city areas of Osaka that have undergone such transformation, like Nakazaki-cho in the Kita ward. The next part of this discussion focuses on these interviews that were conducted in Japanese (with the exception of one interview with an American artist). 


\section{Arts Based in Daily Life}

Many of the artists that participated in interviews emphasised that their work and personal lives were integrated into the area; they lived there as residents and shared their time and surroundings with established locals. One of the artists, who engages in poetry and music, collaborates with other artists to host performances in his house. He stated the following:

I perform my art to provide honest experiences, which is possible because my performances are held in my home, the area in which I go about my daily life. Through our collaborative performances, we can experience trauma that changes our lives completely.

Another poet/photographer manages a guest house in Baika-Shikanjima where he displays photos, installations, and books, and even conducts workshops. The space is used to produce and exhibit his work and those of others. This artist said the following during his interview:

In Baika-Shikanjima, many residents manage their own businesses, free from large outside capital. I feel sad when large condominiums are erected in the area; they destroy our present daily life and freedom, which make my art possible.

A third participant who focuses his talents on music and web design is the manager of a shared house in the ward. The building comprises shops, restaurants, and cafes, and he often hosts art performances in the space. Tourists and a few established residents visit the house even when there are no exhibitions or performances to attend. In his interview, he mentioned the following:

When I was young, I performed my music at art spots managed by other owners. This posed the risk of interferences from residents. I decided that I should take risks too if I wanted the freedom to manage my own art.

One of the participants who specialises in music and installation performances once visited Brooklyn in New York where he became fascinated with musical and painting collaborations. Upon his return to Japan, he explored collaborative art with others in the Baika-Shikanjima area. In due course, he managed to secure an art spot adjacent to his house and invited 
others to collaborate with him. He stated: "At my art spot, many guest artists collaborate. I do not invite famous artists; rather, I invite unknown artists to preserve the experimental identity of the space".

Baika-Shikanjima is famous for its residential artists and their work, and its identity as an arts' hub attracts new artists who often collaborate with established creatives to make more art. This collaboration contributes to a collective identity, which is characteristic of Baika-Shikanjima and which artists willingly share with guests from other areas.

\section{Affordable Lives}

With regard to art studios and accommodation, residential artists use older and more affordable small buildings. One residential architect renovated small buildings on low budgets, while maintaining affordability for artists. Some artists manage small businesses in these buildings, including restaurants, art galleries, boutiques, and cafes. Art galleries, boutiques, and cafes are often regarded as the $\mathrm{ABCs}$ of gentrification. The owners of these businesses are well aware that their presence in the area can initiate gentrification while they repurpose these old buildings. They, however, do not welcome gentrification because it damages their commercial activities. For example, an entrepreneur who participated in the study manages her own bookstore in the area, having moved from another inner-city area in Osaka. She relocated due to an increase in property prices and shops with large outside capital in the area. At present, she sells products to otaku (fans of anime and manga) and gains customers by periodically hosting art exhibitions in her store. During her interview, she said the following:

I am free from a business mindset and gentrification in BaikaShikanjima. Here I can sell my favourite goods and earn enough to live by. I also have friends and neighbours who love arts. They all work independently from capitalism or government politics, which I find comforting.

One of the other participants who manages a cafe where he sometimes hosts live music events said that the low number of chain stores in the area makes his business viable. Chain stores are limited in number because of the smaller buildings and low population density. This participant invites his favourite artists to entertain local residents with live music.

In an attempt to slow down or even prevent gentrification in the area, resident entrepreneurs avoid financial capital from external sources by supporting smaller, independent businesses. One architect, for example, 
repurposed old buildings in the area as public spaces with independent cafes, galleries, and even parks. His aim was to avoid gentrification by welcoming new artists or residents who sympathise with the established residential artists. In his interview, he explained as follows:

The artists in Baika-Shikanjima are becoming older. In order to increase and maintain the value of Baika-Shikanjima, we need new residents. They don't have to be artists, but they should share the idea of art rooted in the daily life of Baika-Shikanjima.

While the residential artists do not earn a sufficient income from their art, they benefit from the affordable accommodation, goods, and services offered by independent businesses in the area. These young, self-taught artists, of whom many do not hold degrees, earn additional income as freelance employees for other business owners, such as web or fashion designers. Some of them are temporary workers at construction companies, hotels, schools, or even non-profit organisations. Their independence from capitalist trends or influences adds value to their artwork, which, in turn, increases their value as artists. Entrepreneurs in the area, therefore, welcome new residents without encouraging an influx of tourists or outside capital. Some residential artists are wary of gentrification yet optimistic about the area's future. Because the daily lives in the area have not changed much during the last two decades (since the opening of USJ in 2001), they think it is unlikely that the area will fall victim to gentrification and they are therefore safe in the margins.

\section{Local Residents' Relationships}

With regard to their integration and acceptance into the area, the majority of the residential artists engage well with longstanding residents. Despite being new, the artists share collective identities and worldviews with the established locals. An embroidery artist, for example, mentioned art exhibitions and performances at art spots adjacent to her house. The audience members, friends and neighbours from the area, did not understand them. Neither the artist nor the audience members were bothered by this reaction, because they all acknowledge that art, unlike other commodities, does not require to be understood by everyone.

Interactions between old and new residents are also encouraged when their children attend the same schools, as is the case in Baika-Shikanjima. Artists who decide to raise their families in the area therefore contribute to a sense of community, understanding, and interaction between different groups of people. 
Furthermore, arts facilitate interaction among participants, including marginalised individuals. For example, one of the artists who participated in this study made a portable shrine (called a mikosi) for the local residents' group. The group now maintains the mikosi and, according to its leader, the artist has managed to involve children and elders in traditional cultural activities. The artwork has turned into more than a religious, cultural, and ritual instrument; it encourages interaction among and between residents and artists.

Another participant manages a business that employs persons with disabilities. In collaboration with a residential artist, he hosts workshops in which the employees and local residents participate to create works of art. He said the following in his interview:

People often discriminate against persons with disabilities because of their unusual behaviours. However, once we interact with these people, we realise that they are not that different. Art is a good way to encourage interaction between persons with disabilities and residents. By hosting these workshops, we can discourage harsh discrimination against handicapped individuals.

One participant in the study (an artist who performs traditional dance) accused artists who work towards uplifting areas are too results-oriented. At one time, he was employed as a staff member at a facility for persons with disabilities. He initiated a project that gave individuals in the area the opportunity to contribute to the making of art, assuming that this would facilitate understanding among the diverse groups of people:

Some residents in Baika-Shikanjima are disabled. They are able to live in the area not only because of the inexpensive rent and commodities, but also due to the local communities. By making available a place of co-presence where these groups can communicate through art, all the participants can experience a sense of belonging.

Another participant - a physical expression artist - is an established local in the area who collaborates with immigrant artists. She had the following to say concerning gentrification in the area:

I had once been indifferent to immigrant artists because I was afraid that the aggregation of artists might accelerate gentrification. Eventually, I realised that many immigrant artists try to root their art in Baika- 
Shikanjima, free from the logic of capitalism. I now collaborate with them in art performances.

Collective identities are strengthened because artists live alongside established locals and interact with residents through their work, as this example illustrates.

\section{Art Exhibition/Performances}

Art spots often host exhibitions of paintings, photos, videos, or various artistic installations, or performances of dances, dramas, music, or poetry. These events are advertised mostly via Facebook, Twitter, or by word-ofmouth. Audience members, of whom some are artists, often return for other performances. After these performances, artists and audience members often enjoy conversation over food and drinks. The number of audience members is limited to 30; most events attract between 10 and 20 people.

Because the buildings are old and small, the performances tend to be intimate, and artists encourage audience members to participate in the productions. These performances often result in laughter: artists and audience members would, for example, burst balloons to make noise, throw toys to make electric sounds, sing a Buddhist prayer, or wear the masks of spirits, and produce harmonious sounds.

Sometimes, artists and audiences walk through the area while performing, and these events attract pedestrians who, in turn, decide to participate. Residents would sometimes complain about the surprising and shocking nature of these performances, although artists do consider such possibilities beforehand. According to a host artist who participated in the interviews, buildings in the area serve particular purposes as residences, shops, or offices. Artists use these ascribed roles in their performances to encourage audiences to reconsider the meaning of their surroundings. For example, the audience would gaze at the landscape and residents while the pedestrians look at the audience. One interviewee mentioned that this bidirectional gaze was the aim of his art performances. Figure 7 shows a scene from a performance in a park in which the artist used cooking utensils and equipment (such as mixing bowls and foils) as musical instruments. Participants then started using the park's chairs, swings, and slides to join him. Children from the area were fascinated and decided to join in. In this way, established residents were involved in the making of art by new residents. 


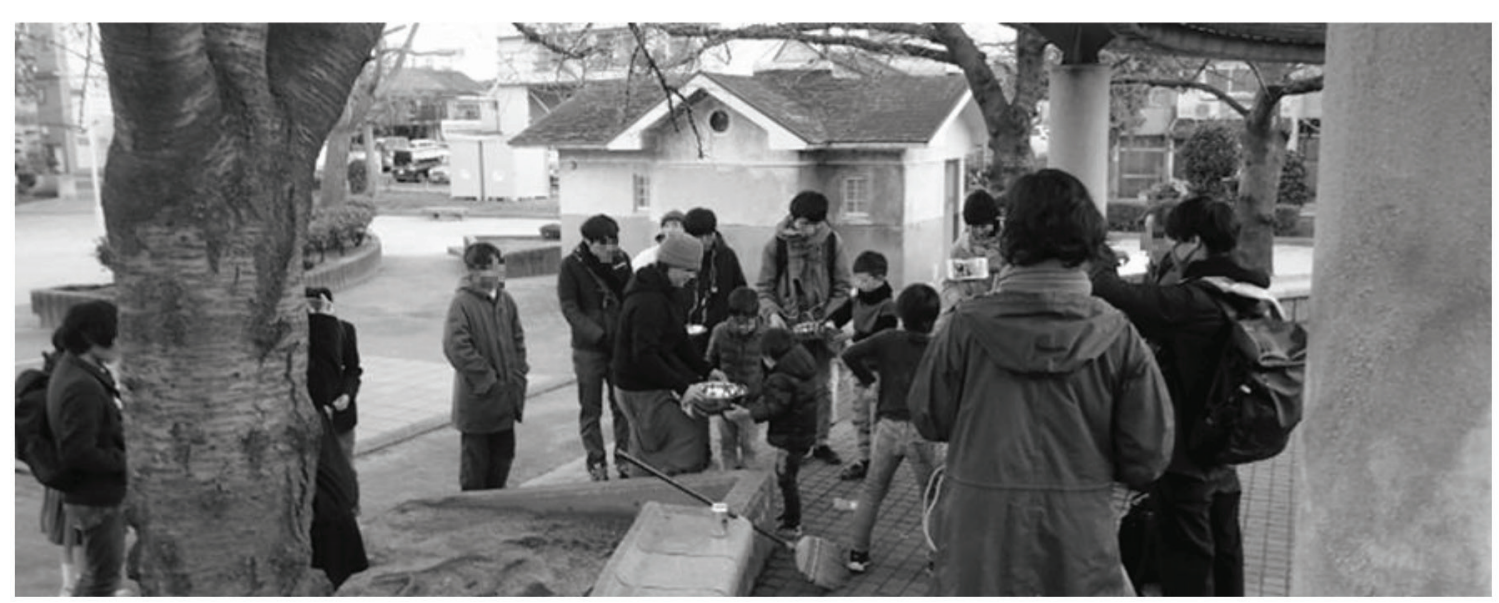

Figure 7: Performance outside buildings.

\section{Venture Out from the Area}

Many artists that participated in the interviews have performed or exhibited their work in other areas, including Tokyo, Kyoto, Kobe, Nara, and abroad. Faced with situation in other areas, some artists accuse Baika-Shikanjima and Osaka of being weak because the artists in the city can hardly collaborate with big corporations or global artists. By participating in collaborations with other artists and audiences around the world, they express resistance against conformity. One of the interviewees, a curator who ran a gallery in BaikaShikanjima, sought to break away from the image of inner-city area. He tried to strengthen his local brand in other areas. Similarly, a musician from BaikaShikanjima mentioned in his interview that he plans to leave the area in the future, but still hopes that other artists would remain there:

I started my music career before I came to Baika-Shikanjima, but I found my identity as an artist based on my daily life in this area. Now I can perform my art outside the area, but I owe much to BaikaShikanjima where I can collaborate with other residential artists.

In this sense, Baika-Shikanjima offers young artists the opportunity to establish themselves and their identities as artists before they move elsewhere to expand their brand or work. Many artists in the interviews informed me that there is little hierarchy between resident artists in Baika-Shikanjima and Osaka, unlike in Tokyo. This allows artists to comfortably live and freely collaborate with others, unrestricted by the clichés of disciplines. 


\section{DISCUSSION}

Gentrification depends on a number of factors: a city's location, demographics, the role of states, the impact of wars or disasters, and the influence of its artists. Not all cities fall victim to gentrification (Ley and Dobson 2008); artists may contribute to the regeneration of city areas without ultimately displacing established residents (Markusen and Gadwa 2010; Grodach et al. 2014). Several studies conducted in North America, Europe, and East Asia show that artists contribute to city justice and work against gentrification (Kirchberg and Kagan 2013; McLean 2014; Enright and McIntyre 2019; Rich 2019; Sasaki 2010; Kee et al. 2014; Ng 2015).

This paper explores the impact of artists on the local community in Baika-Shikanjima, an inner-city area of Osaka's Konohana ward. Like many other areas, the ward has undergone many changes, including a shift from being a manufacturing area to a tourist destination. The area's location makes it attractive to artists. It provides easy and quick access to the largest business, shopping and amusement areas as well as large events (such as the Osaka Expo 2025 and IR), which makes it an even more appealing location. Artists have, therefore, been flocking to the area during the last decade. All these changes indicate the start of gentrification. Despite this, Baika-Shikanjima shows little sign of such changes. The property prices have not increased and there are only a few large condominiums in the area; meanwhile, new residents still live in old, detached albeit renovated buildings. It appears that artists have not promoted gentrification; instead, they have resisted the process of gentrification in the area.

Artists continue with their activities, which include making art or running small businesses, in collaboration with longstanding residents and marginalised groups. In addition, these artists (sometimes unknowingly) encourage social interaction between new residents, established locals, artists, and tourists, which seems to hinder the process of gentrification. Longstanding residents and artists who earn low incomes prefer to stay in the area. Here we may say artists work against gentrification. The question central to this paper is why the collaboration between artists and established residents and others may slow down gentrification.

First, it is important to point out that the young artists in the area do not pursue economic success; they are content with earning little money, or for art for art's sake. In other countries in North America and Europe, for example, quite a few artists are middle-class graduates who earn well (Zukin 1989). Artists who are highly educated and professionally employed earn 
higher incomes, unlike longstanding residents in inner-city areas (Ley 1996). Inequality is foregrounded through art, as only the rich can afford to enjoy it (Oakley et al. 2017). In Baika-Shikanjima, however, many artists work independently, have little access to tertiary education, and take on a variety of additional employment opportunities. As a result, they do not have to adhere to consumer demands. Owing to the excellent location of the area, they have access to affordable products and services and can earn enough money to get by. These artists pursue their artistic identities as opposed to a high income in the area. Those who want to further their careers and improve their financial positions, move away from the area. Other artists stay. In this sense, the area becomes a community of artist refugees who seek to live a comfortable life independent from the constraints of money and society.

Another indication that the area has succeeded in preventing gentrification is the fact that residents do not distinguish between artists, new residents, and longstanding locals. They all share a habitus (Bourdieu 1979). They do not pretend to be anti-bourgeois or creative "neo-Bohemians" (Lloyd 2010). Artists in Baika-Shikanjima do not engage in expressive antigentrification movements; rather, they perform and root their art in the daily life of the area. Artists support local businesses and consume local products because these are affordable. In return, longstanding residents support the artists by participating or attending performances, buying their products, or visiting their shops. Interaction between different groups also seems to have a significant impact on the community. Some artists raise their children in the area, and this encourages interaction between parents from the different groups. That is contrasted with gentrified areas, where newcomers and established residents do not interact (Ajisaka et al. 2019). In addition, resident artists engage with residents who often support their work.

Interaction and understanding between the groups are further promoted by the fact that they are from the same social class. Their earnings are similar and they exchange goods and services. Importantly, many longstanding residents in the area are descent from immigrants, as the area was reclaimed as housing areas for immigrant workers of heavy manufacturing industries during the 1920s. The established locals, therefore, can sympathise with the immigrant artists. According to Castells (1983), the necessary condition for the establishment of a collective identity is neighbourhood residences, which allow residents to share a sense of collective consumption, irrespective of their social class, gender, or profession. In this regard, the public spaces created by artists and longstanding residents may serve as bases for grassroots movements to resist gentrification. 
Finally, their surroundings and interactions with the community make the artists' work possible. For example, they use their dilapidated environments to obtain the materials of their original art products or performances; their surroundings and communities become blank canvases for their artworks. Resident artists also use the inner-city areas and their longstanding residents as landscapes or backgrounds for their work. These site-specific works of art enable artists and residents to reconsider their daily lives (Kwon 2004).

Importantly, art can introduce or reinforce ideas that do not agree with the artist's original intentions. Harvey (1989: cp. 2), for example, points out that art is often used to promote aesthetic politics. Examples of this include the artworks promoted by Nazi Germany or militarised Japan. In sharp contrast to these, the work produced in Baika-Shikanjima is characterised by humour and the daily lives of the community, which encourages a sense of place. Osaka is known for its sense of humour, exemplified by, for example, rakugo (traditional one-person comic storytelling), manzai (two-person stand-up comedy), and sinkigeki (comic theatre). These arts do not focus on politics or economics, but on the lived experiences of the performers and the audience members. Furthermore, artists in this area collaborate with residents (including marginalised groups) to produce art that is free from discrimination and antagonism and which explores their daily lives. In this way, their art has the potential to encourage democracy, diversity, and equality in just cities (Fainstein 2010), unlike the residential segregation that often occurred in revanchist cities (Smith 1996).

Initially, upon their arrival in the area, the artists were considered outsiders with no relation to longstanding residents; eventually, however, they assimilated as friends of the already established residential artists. Boorstin (1964) criticised tourists as being attracted by superficial images. Tourists may, however, also seek authentic experience, as MacCannell (1973) points out. Tourists can assimilate into communities. This is the case with the artists who first arrived as tourists in Baika-Shikanjima.

These artists' approach to involving residents in their artwork relates to the idea of relational aesthetics or participatory arts (Bourriaud 2002; Bishop 2012), which alludes to the potential of art to bring change. Traditionally, art played a significant role in Japan, and Ikegami (2005) argues that similar aesthetic associations can be found in pre-modern Japan. Artists can overcome social barriers through their work when, for example, audience members get the opportunity to participate in performances such as chanoyu (tea ceremony), renga (linking poetry), or haikai (network of poetry). These performances had been restricted to elites or literates until 16th century but 
expanded to ordinary people in the Edo period (17th to 19th century). In BaikaShikanjima, artists, residents, and tourists work together to create public spaces through collaborative art where they can share cultural, social, and aesthetic experiences (Belfiore 2020). Because these areas are not demarcated by physical boundaries, outsiders and marginalised groups are not excluded from the experiences. In these ways, artists unknowingly contribute to the wellbeing of their communities while at the same time resisting gentrification through their daily activities.

As mentioned earlier in the paper, although globalisation accelerates gentrification in many areas of Osaka, Baika-Shikanjima has managed to resist this change. Property developers in Baika-Shikanjima do not build large condominiums to house middle-class outsiders; rather, they collaborate with and invest in artists who occupy abandoned and dilapidated buildings. It is perhaps relevant to note that this area is at risk of tsunamis from earthquakes, which also explains why developers are hesitant to invest in the area.

\section{CONCLUSION}

While the above-mentioned factors might make it seem like the area is immune to gentrification, this might soon change. Art endeavours rarely receive financial support in Osaka, and the government regards art as a cultural resource for redevelopment instead of seeing its potential to promote a participatory democracy (Yoshizawa 2011). The Osaka Expo 2025 and the IR may attract more global capital and international tourists than expected, and the area could become a frontier for global capital and tourism. However, if the community continues to succeed in resisting such drastic changes to the area, Baika-Shikanjima could become a creative inner-city area. In order to achieve this, all its residents should take up principal roles in regenerating the area. This means that artists should continue to involve and engage with residents, root their work in their immediate surroundings, and make art that is authentic and independent from outside influences. They should, in other words, not become zombies for the avantgarde, as Fujita (2016: cp. 1) warns. In doing so, their art may not contribute directly to the economy; instead, they will establish unique identities as artists in Osaka. Hence, this study suggests that inner-city development that improves the wellbeing of local communities is possible and that artists can play a significant role (albeit unknowingly) in resisting gentrification. At present, the COVID-19 pandemic forces us to reconsider our ideas of city development; large aggregations encourage the 
spread of infectious diseases. In the long run, this might have an effect on gentrification. COVID-19 already has a significant impact on tourism, for example. Perhaps, in the future, an alternative form of tourism could be realised instead of the current trend of mass tourism, which is often detrimental to local communities. Artists could work as coordinators of different people, including residents, tourists, marginalised persons and themselves, to develop sustainable inner-city area. The area can be robust in its resistance against gentrification.

\section{ACKNOWLEDGEMENTS}

This research was supported by JSPS KAKENHI grant number 16K04028. The author thanks the artists and residents who took part in this research. The author specially thanks Toshihiro Yamanaka and Seiji Takahashi who guided the author in the Baika-Shikanjima area and introduced interviewees to the author. The author also thanks two anonymous reviewers for valuable comments and discussions. Finally, he would like to thank Enago (www. enago.jp) for the English language review.

\section{COMPLIANCE WITH ETHICAL STANDARDS}

Survey participation and interviews were gained through informed consent of respondents in accordance with procedures standard in Japanese Association for Social Research, Japan.

\section{NOTES}

* Shiro Horiuchi was born in Kyoto, Japan, in 1975. He graduated from Kyoto University in 1998 and obtained $\mathrm{PhD}$ of Science in 2004 from the same university. He majors in regional and mathematical sociology. His main research interest is in the cooperation or coexistence of heterogeneous individuals. For the research in question, he analyses mathematical models, including computer simulations, based on game theory and population growth. He also engages in field work study of regional sociology, particularly interested in communication between urban and rural areas of Japan. He once worked as a coordinator that promotes cooperation among universities, municipalities, companies and non-profit organisations (NPOs). Shiro Horiuchi is now a professor of Hannan University, Japan. He teaches tourism sociology to the university students. Now he tries to analyse how students build creative areas with local residents after their graduation. His selected publications are Problem Solution by Tourism: How We Could Overcome 
Problems Due to Globalization and Depopulation (2020) (in Japanese), "Educational tourism in regional areas: Case studies in a Japanese university" in Global Opportunities and Challenges for Rural and Mountain Tourism (2020: 1-18), "Bridging of different sites by bohemians and tourists: Analysis by agent-based simulation" (2021) in the Journal of Computational Social Science. He is a member of Japanese Association of Mathematical Sociology and Japan Institute of Tourism Research.

\section{REFERENCES}

Ajisaka, M., Nishimura, T., Maruyama, M. and Tokuda, T., eds. 2019. Samayoeru daitoshi Osaka: Toshinkaiki to komyuniti [Wandering large city Osaka: Back to the city movement and community]. Tokyo: Toshindo.

Atkinson, R. and Bridge, G. 2005. Gentrification in a global context: The new urban colonialism. London: Routledge. https://doi.org/10.4324/9780203392089

Belfiore, E. 2020. Whose cultural value? Representation, power and creative industries. International Journal of Cultural Policy 26 (3): 383-397. https://doi.org/10.1080/ 10286632.2018.1495713

Bishop, C. 2012. Artificial hells: Participatory arts and the politics of spectatorship. New York: Verso Books.

Boorstin, D. J. 1964. The image: A guide to pseudo-events in America. New York: Harper \& Row.

Bourriaud, N. 2002. Relational aesthetics. Dijon, France: Les Presses du Reel.

Bourdieu, P. 1979. La distinction: Critique sociale du jugement. Paris: Les Editions de Minuit.

Butler, T. and Lees, L. 2006. Super-gentrification in Barnsbury, London: Globalization and gentrifying global elites at the neighbourhood level. Transactions of the Institute of British Geographers 31 (4): 467-487. https://doi.org/10.1111/j.14755661.2006.00220.x

Cai, G., Xu, L., Gao, W., Hong, Y., Ying, X., Wang, Y. and Qian, F. 2020. The positive impacts of exhibition-driven tourism on sustainable tourism, economics, and population: The case of the Echigo-Tsumari Art Triennale in Japan. International Journal of Environmental Research and Public Health 17 (5): 1489. https://doi. org/10.3390/ijerph17051489

Cameron, S. and Coaffee, J. 2005. Art, gentrification and regeneration: From artist as pioneer to public arts. European Journal of Housing Policy 5 (1): 39-58. https:// doi.org/10.1080/14616710500055687

Castells, M. 1983. The city and the grassroots: A cross-cultural theory of urban social movements. California: University of California Press.

Colomb, C. and Novy, J. 2016. Protest and resistance in the tourist city. London: Routledge. https://doi.org/10.4324/9781315719306

Enright, T. E. and McIntyre, C. 2019. Art and neighbourhood change beyond the city centre. Canadian Journal of Urban Research 28 (1): 34-49.

Fainstein, S. S. 2010. The just city. New York: Cornell University Press. https://doi. org/10.7591/9780801460487 
Florida, R. 2017. The new urban crisis: How our cities are increasing inequality, keeping segregation, and failing the middle class and what we can do about it. New York: Basic Books. 2002. The rise of the creative class. New York: Basic Books.

Fujita, N. 2016. Chiiki art: Bigaku, seido, Nihon [Local art: Aesthetics, institution, and Japan]. Tokyo: Horinouchi Shuppan.

Fujitsuka, Y. 2017. Jentorifikeshon [Gentrification]. Tokyo: Kokon Shoin.

Glass, R. 1964. Introduction: Aspects of change. In London: Aspects of change, ed. Center for Urban Studies, xviii-xviix. London: MacKibbon and Kee.

Gotham, K. F. 2005. Tourism gentrification: The case of New Orleans' Vieux Carre (French Quarter). Urban Studies 42 (7): 1099-1121. https://doi. org/10.1080/00420980500120881

Gravari-Barbas, M. and Guinand, S. 2017. Tourism and gentrification in contemporary metropolises: International perspectives. London: Routledge. https://doi. org/10.4324/9781315629759

Grodach, C. 2010. Beyond Bilbao: Rethinking flagship cultural development and planning in three California cities. Journal of Planning Education and Research 29 (3): 353366. https://doi.org/10.1177/0739456X09354452

Grodach, C., Foster, N. and Murdoch III, J. 2014. Gentrification and the artistic dividend: The role of the arts in neighbourhood change. Journal of the American Planning Association 80 (1): 21-35. https://doi.org/10.1080/01944363.2014.928584

Hamnett, C. 1991. The blind men and the elephant: The explanation of gentrification. Transactions of the Institute of British Geographers 16 (2): 173-189. https://doi. org/10.2307/622612

Harvey, D. 2012. Rebel cities: From the right to the city to the urban revolution. New York: Verso Books.

. 1989. The condition of postmodernity: An enquiry into the origins of cultural change. Cambridge, MA: Blackwell.

Horiuchi, S. 2017a. Entrepreneurs' networks at rural market: Developing a creative village in the Yamagata Prefecture, Japan. Economics and Sociology 10 (3): 251-265. https://doi.org/10.14254/2071-789X.2017/10-3/18

. 2017b. Coordinators bridge residents and artists in regional Japan: A case study of the art project Hanarart. International Journal of Asia Pacific Studies 13 (2): 1-22. https://doi.org/10.21315/ijaps2017.13.2.1

Ikegami, E. 2005. Bonds of civility: Aesthetic networks and the political origins of Japanese culture. Cambridge, England: Cambridge University Press.

Jacobs, J. 1961. The death and life of great American cities. New York: Random House Publishing.

Kawaguchi, N. 2008. How street fashion is shaped in Horie, a commercially regenerated area [in Japanese]. Jinbun Chiri 60 (5): 443-461. https://doi.org/10.4200/jjhg.60.5_443

Kee, Y., Kim, Y. and Lee, Y. 2014. Sing, dance, and be merry: The key to successful urban development? Asian Social Science 10 (9): 245-261. https://doi.org/10.5539/ass. v10n9p245

Kim, C. 2019. Creative labor as moral and ethical subjects and its limitation: Creative City Yokohama, Japan. Inter-Asia Cultural Studies 20 (1): 39-55. https://doi.org/10.10 80/14649373.2019.1576396 
Kirchberg, V. and Kagan, S. 2013. The roles of artists in the emergence of creative sustainable cities: Theoretical clues and empirical illustrations. City, Culture and Society 4 (3): 137-152. https://doi.org/10.1016/j.ccs.2013.04.001

Kirmizi, M. 2019. Japanese gentrification from a local community perspective. City \& Community 18 (2): 618-637. https://doi.org/10.1111/cico.12391

. 2016. Branding of Horie, Nishi Ward from the viewpoint of long-term residents: A case of urban change in Osaka City after the collapse of the economic bubble. UrbanScope 7: 45-55.

Kwon, M. 2004. One place after another: Site-specific art and locational identity. Cambridge, MA: MIT Press.

Lees, L. 2003. Super-gentrification: The case of Brooklyn Heights, New York City. Urban Studies 40 (12): 2487-2509. https://doi.org/10.1080/0042098032000136174

Lees, L., Shin, H. B. and Lopez-Morales, E. 2016. Planetary gentrification. Cambridge, England: Polity Press.

.2015. Global gentrifications: Uneven development and displacement. Bristol: Policy Press. https://doi.org/10.1332/policypress/9781447313472.001.0001

Lees, L., Slater, T. and Wyly, E. 2008. Gentrification. London: Routledge. https://doi. org/10.4324/9780203940877

Lefevre, H. 1968. Le droit a la Ville. Paris: Editions Anthropos.

Ley, D. 2003. Artists, aestheticisation and the field of gentrification. Urban Studies 40 (12): 2527-2544. https://doi.org/10.1080/0042098032000136192

. 1996. The new middle class and the remaking of the central city. Oxford: Oxford University Press.

Ley, D. and Dobson, C. 2008. Are there limits to gentrification? The contexts of impeded gentrification in Vancouver. Urban Studies 45 (12): 2471-2498. https://doi. org/10.1177/0042098008097103

Lloyd, R. 2010. Neo-bohemia: Art and commerce in the postindustrial City (2nd ed.). New York: Routledge. https://doi.org/10.4324/9780203854662

MacCannell, D. 1973. The tourist: A new theory of the leisure class. California: University of California Press.

Markusen, A. 2006. Urban development and the politics of a creative class: Evidence from a study of artists. Environment and Planning A: Economy and Space 38: 19211940. https://doi.org/10.1068/a38179

Markusen, A. and Schrock, G. 2006. The artistic dividend: Urban artistic specialisation and economic development implications. Urban Studies 43 (10): 1661-1686. https:// doi.org/10.1080/00420980600888478

Markusen, A. and Gadwa, A. 2010. Arts and culture in urban or regional planning: A review and research agenda. Journal of Planning Education and Research 29 (3): 379-391. https://doi.org/10.1177/0739456X09354380

McLean, H. E. 2014. Cracks in the creative city: The contradictions of community arts practice. International Journal of Urban and Regional Research 38 (6): 2156-2173. https://doi.org/10.1111/1468-2427.12168

Ng, M. K. 2015. Knowledge and power in regenerating lived space in Treasure Hill, Taipei 1960s-2010: From squatter settlement to a co-living artist village. Planning Perspectives 30 (2): 253-270. https://doi.org/10.1080/02665433.2014.934711 
Novak, D. 2019. The arts of gentrification: Creativity, cultural policy, and public space in Kamagasaki. City and Society 31 (1): 94-118. https://doi.org/10.1111/ciso.12195

Oakley, K., Laurison, D., O'Brien, D. and Friedman, S. 2017. Cultural capital: Arts graduates, spatial inequality, and London's impact on cultural labor markets. American Behavioral Scientist 61 (12): 1510-1531. https://doi. org/10.1177/0002764217734274

Osaka City History Compilation Office. 1999. Osakasi no rekishi [History of Osaka city]. Osaka: Sogensya.

Pallagst, K., Wiechmann, T. and Martinez-Fernandez, C. 2013. Shrinking cities: International perspective and policy implications. New York: Routledge. https:// doi.org/10.4324/9780203597255

Rich, M. A. 2019. "Artists are a tool for gentrification": Maintaining artists and creative production in arts districts. International Journal of Cultural Policy 25 (6): 727742. https://doi.org/10.1080/10286632.2017.1372754

Sasaki, M. 2010. Urban regeneration through cultural creativity and social inclusion: Rethinking creative city theory through a Japanese case study. Cities 27 (Suppl. 1): S3-S9. https://doi.org/10.1016/j.cities.2010.03.002

Sassen, S. 2001. The global city: New York, London, Tokyo (2nd ed.). New Jersey: Princeton University Press. https://doi.org/10.1515/9781400847488

Sawangchot, V. 2016. Creative city and the sustainable life: A study on the making of cultural spaces in Osaka and Bandung. Journal of Urban Culture Research 12: 54-69.

Smith, N. 2002. New globalism, new urbanism: Gentrification as global urban strategy. Antipode 34 (3): 427-450. https://doi.org/10.1111/1467-8330.00249

1996. The new urban frontier: Gentrification and the revanchist city. London: Routledge.

Soja, E. W. 1996. Thirdspace: Journeys to Los Angeles and other real-and-imagined places. New Jersey: Blackwell.

Stern, M. J. and Seifert, S. C. 2010. Cultural clusters: The implications of cultural assets agglomeration for neighborhood revitalization. Journal of Planning Education and Research 29 (3): 262-279. https://doi.org/10.1177/0739456X09358555

Tanaka, Y. 2019. Space and art: In collaboration with the public in public spaces. The Global Journal of Researches in Engineering 19 (2): 47-53.

Urry, J. and Larsen, J. 2011. The tourist gaze 3.0. California: Sage Publications. https://doi. org/10.4135/9781446251904

Woronkowicz, J. and Noonan, D. S. 2019. Who goes freelance? The determinants of selfemployment for artists. Entrepreneurship Theory and Practice 43 (4): 651-672. https://doi.org/10.1177/1042258717728067

Yoshizawa, Y. 2011. Geijutsu wa shakai wo kaeruka: Bunkaseisan no shakaigaku karano sekkin [Can art reform the society? Approaches from sociology of culture production]. Tokyo: Seikyusha.

Zukin, S. 1989. Loft living: Culture and capital in urban change. Baltimore: Johns Hopkins University Press. 